\author{
V.M. Yurov ${ }^{1}$, E.N. Eremin ${ }^{2}$, V.Ch. Laurinas ${ }^{1}$, S.S. Kasimov ${ }^{1}$ \\ ${ }^{1}$ Ye.A. Buketov Karaganda State University, Kazakhstan; \\ ${ }^{2}$ Omsk State Technical University, Russia \\ (E-mail: exciton@list.ru)
}

\title{
Dissipative processes in tribology
}

\begin{abstract}
In the paper the dissipative process is considered as the basis of the nature of external friction in solids. It is shown that non-equilibrium processes in the tribosystem can lead to a decrease in the production of entropy and, consequently, the intensity of wear and stably proceed with the formation of dissipative structures during self-organization. It was found that the first term can reach $f_{e}=10^{-3}-10^{-4}$ by using $X_{m}, \rho_{m}$ and $W\left(X_{m}\right)$ in the mode of using special lubricants. In space, the effect of oil filters is absent. It uses solid lubricants which include substances applied to the surface of parts in the form of films that have a shear strength that is significantly less than that of the part material. An expression for the friction coefficient is obtained, which takes into account the surface geometry and its physical properties. It was concluded that homogeneous metal pairs should not be used in friction antifriction pairs. It is shown that a decrease in the dry friction coefficient is possible due to a decrease in surface energy. In this case, friction pairs are used, in which the electron work function differs significantly. This leads to a difference in the contact potential difference and, accordingly, to a decrease in the surface energy. It is shown that the friction coefficient depends on the fractal structure of the surface of many solids and this is their characteristic property.
\end{abstract}

Keywords: dissipative process, friction, wear, surface, entropy, fractal.

\section{Introduction}

The origins of tribology - the science of friction, wear and lubrication of machines - go into the depths of human history [1-4]. The first period of history includes the accumulation of human tribological knowledge from prehistoric times to the end of the XVI century. In the XVII-XVIII centuries, the birth of the science of friction, later called «tribology», takes place. In the XIX century, the progress of technology (above all - the development of railways) highlights the problems of a tribological nature. In a word, before the beginning of the 20th century, tribology went a long and glorious way, successfully solving the tasks put forward by practice, and the progress of technology was hardly delayed for a long time because of the impossibility of solving tribological problems [1-4].

The beginning of the XXI century is especially important for friction units operating in extreme conditions (aerospace, atomic energy, high-speed transport, equipment for the development of the Ocean, the deep bowels of the Earth, etc.) [5,6]. The urgent task is to summarize the experimental data, predict reliability and resource in a wide range of changes in voltages, temperatures, environments, exposure to fields of different physical nature (acoustic, electromagnetic, radiation, etc.) [7].

The beginning of the XXI century laid a comprehensive study of the tribological properties of nanostructures and nanomaterials [8-11]. The use of nano-coatings can significantly reduce the coefficient of friction while maintaining wear resistance, increase the viscosity of coatings while maintaining anticorrosion properties and increasing the operating temperature by $50{ }^{\circ} \mathrm{C}$. All this is especially important in the field of engineering. Nanostructured materials and suspensions are used to create nanocoatings. Special additives are introduced into the coatings that modify their structure and provide the necessary properties.

Selective transference under friction (the effect of wearlessness) is a natural phenomenon, it is recognized as the scientific discovery of the USSR (D. Garkunov and I. Kragelsky) No. 41 dated September 13, 1966 [12]. In practice, the «wear-free» functioning of friction units is most often achieved by using metalplating lubricants in real tribo-splicing: oils, grease, self-lubricating materials and coatings [13]. Historically, the first studies of the mechanism of selective transfer [14] were studies of the thickness, roughness, microhardness and microstructure formed on rubbing surfaces during friction of a copper alloy on steel in an aqueous or alcoholic solution of glycerol and a visually observed copper servo film. It has been established that the servo-film film spontaneously arising during frictional interaction has a thickness of no more than $1 . . .2$ microns, and its mechanical and physicochemical properties are significantly different from the properties of ordinary compact copper. 
Considering from the standpoint of green tribology, the effect of wearlessness under friction, the first thing that attracts attention is the conceptual possibility of friction without wear, which has been repeatedly confirmed experimentally and fully corresponds to the principles of green chemistry, engineering and tribology [15]. In other words, the saving of material resources during the implementation of selective transfer is achieved automatically and not only by minimizing wear, but also by increasing the resource life of engineering products.

Secondly, the friction coefficients of $10^{-3}$ in the implementation of super-anti-friction properties clearly lead to energy savings, which also corresponds to the principles of green science [15].

It is noted that the nature of external friction is the dissipative process [16]. Relaxation internal friction is a dissipative process found in the study of the phenomenon of inelasticity. The intensity of relaxation processes found on the temperature-frequency dependences of the dissipation of a part of the energy of an external force field mechanical effect depends on the ratio of speed or frequency from this effect and temperature $T$. Depending on this ratio, the reaction of the system under investigation to external influence varies from elastic to viscoelastic.

In this paper, the dissipative process is considered as the basis of the nature of external friction in solids.

\section{Probability of dissipative processes}

Crystal defects (impurity ions, color centers, etc.) will be considered as a system of noninteracting particles immersed in a thermostat (tribological system). Quantum transitions due to the interaction of defects with a thermostat will be dissipative (with probability $\mathrm{P}$ ) as opposed to interaction with an external field (with probability F). Dissipative processes lead to the fact that the secondary field (system response) is always smaller than the primary one, which causes the formation of defects $[17,18]$.

Since the subsystem of defects exchanges only energy with a thermostat, the corresponding ensemble of particles will be canonical. In this case, the expression for statistical entropy is:

$$
S=-k \sum_{i} f_{i} \ln f_{i}
$$

where $f_{i}$ is the distribution function; $\mathrm{k}$ is the Boltzmann constant.

Differentiating (1) in time and transforming, we get:

$$
\frac{d S}{d t}=\frac{k}{2} \sum_{i, j}\left(\ln f_{i}-\ln f_{j}\right)\left(P_{i j} f_{i}-P_{j i} f_{j}\right),
$$

where $P_{i j}$ is the transition probability from the initial $i$ (with energy $E_{i}$ ) to the excited state $j$ (with energy $E_{j}$ ).

For dissipative processes, the principle of detailed equilibrium has the form:

$$
\frac{g_{i} P_{i j}}{g_{j} P_{j i}}=e^{\frac{E_{j}-E_{i}}{k T}},
$$

where $g_{i}, g_{j}$ are statistical weights for levels $E_{i}$ and $E_{j}$.

Then (1) takes the form:

$$
\frac{d S}{d t}=\frac{k}{2} P_{i j}\left(\ln f_{i}-\ln f_{j}\right)\left(f_{i}-\frac{g_{i}}{g_{j}} f_{j} e^{-\frac{E_{i}-E_{j}}{k T}}\right),
$$

Canonical distribution function:

$$
f_{i j}=\frac{1}{Z} e^{-E_{i j} / k T},
$$

where is the statistic sum:

$$
Z=e^{-G / k T},
$$

where $G$ is the Gibbs potential (free energy) of the thermostat + defect system.

We assume that the non-configuration part of the Gibbs potential linearly depends on the concentration of $N$ defects:

$$
e^{-G / k T}=\sum_{N} h(N),
$$

where $h(N)=\omega(N) \cdot e^{-G / k T} ; \omega(N)$ - statistical weight. 
After simple calculations, it is easy to show that the function $h(N)$ is the Gaussian distribution near the equilibrium value with a small dispersion, i.e.:

Substituting (8) into (7), we have:

$$
h(N)=h(\bar{N}) e^{-\Delta \bar{N}^{2} / N}
$$

$$
e^{-G / k T}=h(\bar{N}) \sum_{\Delta N} e^{-\Delta \bar{N}^{2} / \bar{N}}
$$

To estimate the sum in (9), we replace it with the integral:

Then (9) takes the form:

$$
\sum_{\Delta N} e^{-\Delta \bar{N}^{2} / \bar{N}}=\int_{-\infty}^{+\infty} e^{-x^{2} / \bar{N}} d x=\sqrt{\pi x}
$$

$$
e^{-G / k T}=h(\bar{N})(\pi \bar{N})^{1 / 2}
$$

Using (7) and taking the logarithm from (10), we find:

$$
G / k T=-\ln \omega(\bar{N})+\frac{G(\bar{N})}{k T}+\frac{1}{2} \ln (\pi \bar{N}),
$$

where $G(\bar{N})$ is the part of the total Gibbs potential associated with the concentration of defects. From the evaluation of the first logarithmic term follows:

$$
\ln \omega(\bar{N})=N \ln \left(1+\frac{\bar{N}}{N}\right)+\bar{N} \ln \frac{N+\bar{N}}{N} .
$$

By approximating the logarithm in the first term of the right-hand side of (12), the first term of its expansion in a series, and the second term, expressing through the Gibbs potential of the system of defects $G^{f}$, we get:

$$
\ln \omega(\bar{N})=\bar{N}+\bar{N} G^{f} / k T .
$$

Substituting (13) into (11) and neglecting the term $1 / 2 \ln (\pi \bar{N})$ as compared with $\bar{N}$, we get:

$$
G=G(\bar{N})-\bar{N} G^{f}-\bar{N} k T \text {. }
$$

As above, assuming that the thermodynamic potential $G(\bar{N})$ depends on the equilibrium number of defects $C^{f}$ in a linear fashion, that is:

$$
G=G^{0}+\bar{N} G^{f},
$$

where $G^{0}$ is the thermodynamic potential of the thermostat, we find:

$$
G=G^{0}-\bar{N} k T \text {. }
$$

Using (8), expression (6) is converted to the form:

Substituting (16) into (4), we find

$$
Z=e^{-G^{0} / k T} e^{\bar{N}} \text {. }
$$

$$
\frac{d S}{d t}=\frac{k}{2} \sum_{i, j} P_{i j} e^{G^{0} / k T} e^{-\bar{N}} e^{-E_{i} / k T}\left(\frac{E_{j}-E_{i}}{k T}\right)\left(1-\frac{g_{i}}{g_{j}} e^{2 \frac{E_{i}-E_{j}}{k T}}\right) .
$$

Neglecting the small terms and replacing in (18) the sum with the integral we get:

$$
P=\frac{2 \Delta S}{k \tau} \exp \left\{-\frac{\Delta E_{m}-G^{0} / N}{k T}\right\},
$$

where $\Delta S$ is the change in entropy in the dissipative process; $\Delta E_{m}$ is the average value of the energy of the ground state of defects; $\tau$ is the relaxation time.

\section{Friction and entropy}

In the dissipative process the friction fm changes completely. Then follows from (19):

$$
f_{m}=\frac{2}{k}\left(\frac{d S}{d t}\right) \exp \left\{-\frac{\Delta E_{m}-G^{0} / N}{k T}\right\}=\frac{2 \Delta S}{k \tau} \exp \left\{-\frac{\Delta E_{m}-G^{0} / N}{k T}\right\} .
$$

Nonequilibrium processes in the tribosystem can lead to a decrease in the production of entropy and, consequently, the intensity of wear and stably proceed with the formation of dissipative structures during 
self-organization [19-23]. The process of self-organization can begin only after the system has passed through instability [19-23]. The system can lose stability with a negative excess production of entropy (according to the Lyapunov function [21]). For the tribosystem to self-organize, more than one independent process should take place in it [19-23]. The paper [24] gives the formula:

$$
f_{e}=\left(\frac{d S}{d t}\right)_{e}=X_{m} \cdot \rho_{m} \cdot W\left(X_{m}\right)
$$

where $X_{m}$ is the thermodynamic force that causes mass transfer (stress gradients or chemical potentials, respectively, for deformation or diffusion), $\rho m$ is the average density of the substance involved in mass transfer, $W\left(X_{m}\right)$ is the average mass transfer rate, depending on $X_{m}$, will increase with $X_{m}$.

From (21) follows:

$$
X_{m} \cdot \rho_{m} \cdot W\left(X_{m}\right) \rightarrow 0 .
$$

From (22), it follows that the first term in (20) can reach $\mathrm{fe}=10^{-3}-10^{-4}$ by using $X_{m}, \rho m$ and $W\left(X_{m}\right)$ in the mode of using special lubricants.

According to the method of incorporation into the lubrication system, the filters are divided into series and parallel, according to the dispersity of the filtrate filtered out - into filters of coarse and fine cleaning. Detailed classification of oil filters is shown in Figure 1.

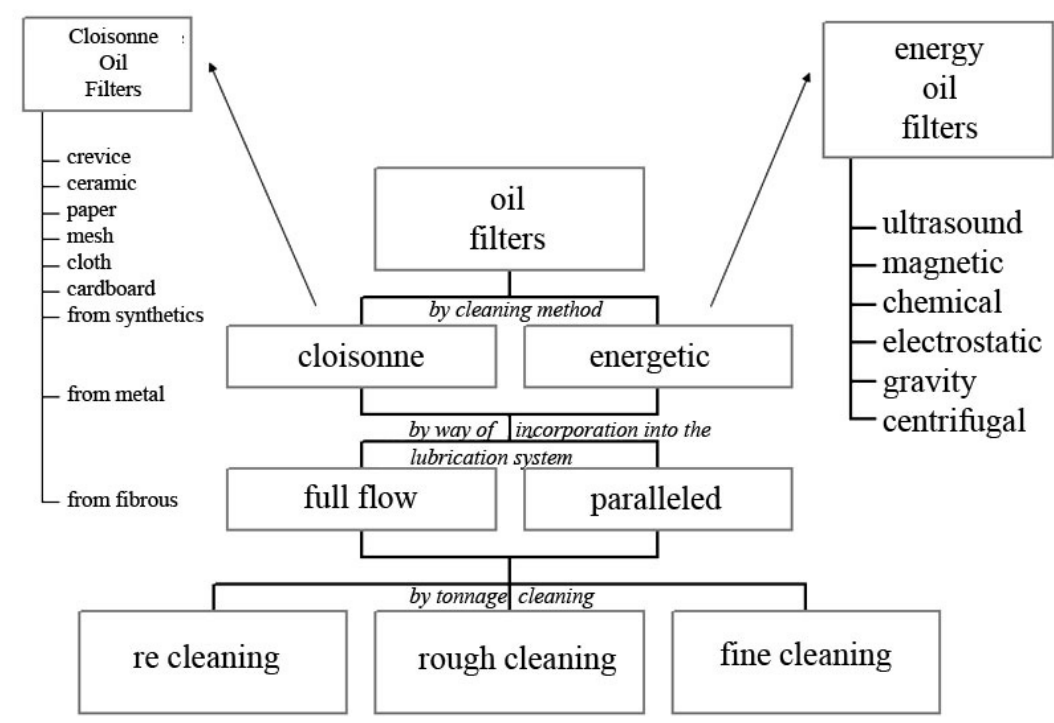

Figure 1. Classification of oil filters [25]

In space, the effect of oil filters is absent. It uses solid lubricants (TSP) which include substances applied to the surface of parts in the form of films that have a shear strength that is significantly lower than that of the part material. Films of sulfides $\left(\mathrm{MoS}_{2}, \mathrm{WS}_{2}, \mathrm{PbS}, \mathrm{NbS}_{2}\right.$, etc.), selenides ( $\mathrm{MoS}_{2}, \mathrm{WSe}_{2}, \mathrm{NaSe}_{2}$, etc.), tellurides $\left(\mathrm{MoTe}_{2}, \mathrm{WTe}_{2}, \mathrm{NbTe}_{2}, \mathrm{TaTe}_{2}\right)$, chlorides $\left(\mathrm{CoCl}, \mathrm{PbCl}_{2}, \mathrm{CdCl}_{2}, \mathrm{CuCl}\right)$, fluorides $\left(\mathrm{AlF}_{3}, \mathrm{CaF}_{2}, \mathrm{BaF}_{2}\right.$, $\left.\mathrm{MgF}_{3}\right)$, iodides $\left(\mathrm{Cal}_{2}, \mathrm{Pbl}_{2}, \mathrm{BiI}_{3}\right)$, metal oxides $\left(\mathrm{PbO}, \mathrm{Bi}_{2} \mathrm{O}_{3}, \mathrm{PbO}+\mathrm{SiO}_{2}\right)$, graphite, boron nitride, etc. In the Table 1 the density, coefficient of friction and the operating temperature of some sulfides, selenides and metal tellurides are shown.

$\mathrm{T}$ a b l e 1

Characteristics of TSP [25]

\begin{tabular}{|c|c|c|c|c|}
\hline \multirow{2}{*}{ Connections } & \multirow{2}{*}{ Density, $\mathrm{g} / \mathrm{sm}^{3}$} & \multirow{2}{*}{ Coefficient friction } & \multicolumn{2}{|c|}{ Maximum permissible operating temperature, ${ }^{\circ} \mathrm{C}$} \\
\cline { 3 - 5 } & 2 & 3 & 4 & vacuum \\
\hline 1 & 7.40 & $0.07-0.14$ & 500 & 5 \\
\hline $\mathrm{Bi}_{2} \mathrm{~S}_{3}$ & 4.28 & $0.17-0.41$ & 520 & - \\
\hline $\mathrm{CuS}$ & 5.60 & 0.18 & 450 & - \\
\hline $\mathrm{Cu}_{2} \mathrm{~S}$ & $4.8-5.16$ & $0.02-0.3$ & 1100 & 400 \\
\hline $\mathrm{MoS}$ & $5.9-6.0$ & 0.04 & 1300 & 400 \\
\hline $\mathrm{NbS}$ & & & & \\
\hline
\end{tabular}




\begin{tabular}{|c|c|c|c|c|}
\hline & & & \multicolumn{2}{|c|}{ Continuation of Table 1} \\
\hline 1 & 2 & 3 & 4 & 5 \\
\hline $\mathrm{PbS}$ & $7.5-7.59$ & 0.37 & 410 & 500 \\
\hline $\mathrm{TaS}_{2}$ & 7.16 & 0.06 & 1500 & - \\
\hline $\mathrm{WS}_{2}$ & $7.5-7.63$ & $0.03-1.6$ & 1400 & 500 \\
\hline $\mathrm{NbSe}_{2}$ & 6.25 & $0.06-0.17$ & 1350 & 350 \\
\hline $\mathrm{MoSe}_{2}$ & 6.90 & $0.03-0.22$ & 1350 & 400 \\
\hline $\mathrm{WS}_{2}$ & 9.0 & $0.02-0.18$ & 1350 & 350 \\
\hline $\mathrm{MoTe}_{2}$ & 7.8 & $0.10-0.34$ & 1240 & 400 \\
\hline $\mathrm{WTe}_{2}$ & 9.44 & $0.27-0.49$ & 1020 & - \\
\hline $\mathrm{VTe}_{2}$ & - & 0.22 & 450 & 500 \\
\hline
\end{tabular}

\section{Friction and energies of the ground state of defects}

We estimate the contribution of the energy of the ground state of defects:

$$
f_{a} \approx \exp \left\{-\frac{\Delta E_{m}}{k T}\right\}
$$

Based on the concepts of the kinetic thermofluctuation concept of solid strength developed by S.N. Zhurkov and co-workers [26, 27], in [28] proposed physical and computational models of wear of friction surfaces.

The proposed models are based on a fundamental pattern [26], which relates stress, absolute temperature, and durability:

where $\sigma$ is the breaking stress:

$$
t=\tau_{0} \exp \left[\left(U_{0}-\gamma \sigma\right) / k T\right]
$$

$$
\sigma=(1 / \gamma)\left(U_{0}-k T \ln \left(t / \tau_{0}\right)\right)
$$

where $t$ is the time to failure (durability) of the sample under load, $\mathrm{s} ; \tau_{0}=\left(10^{-12} \ldots 10^{-13}\right), \mathrm{c}$ - the oscillation period of atoms in a solid; $U_{0}$ is the interatomic bond energy, $\mathrm{J} ; T$ is the thermodynamic temperature, $\mathrm{K}$; $k=1.38 \cdot 10^{-23} \mathrm{~J} / \mathrm{K}$ is the Boltzmann constant; $\gamma$ - parameter (fitting), having the dimension of volume, $\mathrm{m}^{3}$; activation energy of destruction $\Delta U=\left(U_{0}-\gamma \sigma\right)$.

For the energy of the ground state of defects in [28], it was found that for typical defects on metal surfaces it is $\Delta E \approx 2-5 \mathrm{~J}$. Then for $k T \approx 0.3 \mathrm{eV}$, we get $\exp (-33) \approx 10^{-15} \approx 1$ and $f_{a}=1$.

\section{Friction, roughness, fracture energy of defects and Gibbs energy}

Remain the third term in equation (19), which can be brought to mind:

$$
f_{G}=\frac{A_{r}}{G^{0}} \cdot N
$$

where $A_{r}$ is the destruction energy of defects; $N$ - contact roughness; $G^{0}$ - Gibbs energy.

Nowadays, in mechanical engineering, high-alloyed, including stainless steels are often used for critical machine parts, the processing of which is complicated by traditional mechanical methods. Particularly problematic is obtaining accurate small holes. For this case, the most effective is the use of the EDM method of piercing a hole [29].

The mathematical model describing the dependence when using water as a working fluid has the form:

$$
N=0,11 \cdot E^{0,66} \cdot F^{-0,26},
$$

where $E$ is the pulse energy, $\mathrm{mJ} ; F$ is the pulse frequency, $\mathrm{kHz}$.

GOST defined six types of directions of irregularities that are selected when recording a profilogram: parallel, perpendicular, intersecting, arbitrary, circular and radial. When removing profilograms from friction surfaces, the first two types are most often used [30]. The concepts parallel and perpendicular are related to the direction of friction during the operation of the tribo-conjugation.

The arithmetic average of the $R_{a}$ profile is determined by the arithmetic average of the absolute values of the profile deviations within the base length:

$$
R_{a}=\frac{1}{\ell} \int_{0}^{\ell}|y| d x \quad \text { or } \quad R_{a} \frac{1}{n} \sum_{i=1}^{n}|y|,
$$

where: $\ell$ is the base length, $n$ is the number of selected profile points on the base length. 
The height of the profile of irregularities at ten points $\mathrm{Rz}$ is defined as the sum of the average absolute values of the heights of the five largest profile protrusions and the depths of the five largest cavities of the profile within the base length:

$$
R_{z}=\frac{\sum_{i=1}^{5}|y p m i|+\sum_{i=}^{5}|y v m i|}{5},
$$

where $y p m i$ is the height of the $i$-th largest profile protrusion; $y v m i$ is the depth of the $i$-th largest depression of the profile.

The greatest height $R_{\max }$ of the profile is the distance between the line of the protrusions of the profile and the line of the cavities of the profile within the base length. The average step of the irregularities of the profile $S_{m}$ is the average step of the local projections of the profile within the base length. The average pitch of the local projections of the profile $S$ is the average pitch of the local projections of the profile within the base length. The relative profile reference length $t_{p}$ is the ratio of the profile length to the base length and is defined as

$$
t_{p}=\frac{\sum_{i=1}^{n} b_{i}}{\ell} .
$$

The cross section level of the profile $p$ is the distance between the profile protrusion line and the line intersecting the profile equidistantly of the profile protrusion line. When studying profilograms, one should take into account that the vertical and horizontal scales of increasing the surface profile are different and real irregularities have a much smaller angle of inclination than it looks on profilograms.

Consider in (26) $-A_{r}$ is the damage energy of defects [31,32]. Work $A(J)$, spent on the destruction of contacts is proportional to the newly formed surface of the particles of the destroyed product:

$$
A_{r}=\gamma \Delta S=K_{R} D^{2}
$$

where $\gamma$ is the temporary compressive resistance $\left(\mathrm{Nm} / \mathrm{m}^{2}\right), \Delta S$ is the area of the newly formed surface $\left(\mathrm{m}^{2}\right)$, $K_{R}$ is the proportionality coefficient $\left(\mathrm{Nm} / \mathrm{m}^{2}\right) ; D$ is the characteristic size of the contact (m).

Equation (31) corresponds to the Rittinger hypothesis [33]. If during the destruction of a cubic-shaped contact, energy is expended mainly on volume deformation, then in this case the work performed is directly proportional to the change in its initial volume and is determined by the Kirpichev-Kik formula [34, 35]:

$$
A_{r}=K \Delta V=K_{K} D^{3} \text {, }
$$

where $K$ and $K_{K}$ are the proportionality coefficients $\left(\mathrm{Nm} / \mathrm{m}^{3}\right) ; \Delta V$ is the deformed volume $\left(\mathrm{m}^{3}\right)$.

Rebinder [36] combined both hypotheses and in this case the total work of destruction is equal to:

$$
A=K_{R} D^{2}+K_{K} D^{3}
$$

According to Bond's hypothesis [37], the total work of failure is proportional to the geometric mean between the volume and the contact surface area:

$$
A=K_{B} \sqrt{D^{2} D^{3}}=K_{B} D^{2,5} .
$$

All formulas (31)-(34) differ in proportionality coefficients and indicators of the degree of contact diameter. This indicator is related to the dimension of the contact surface, which in the modern sense has a fractal nature [38] (Fig. 2).
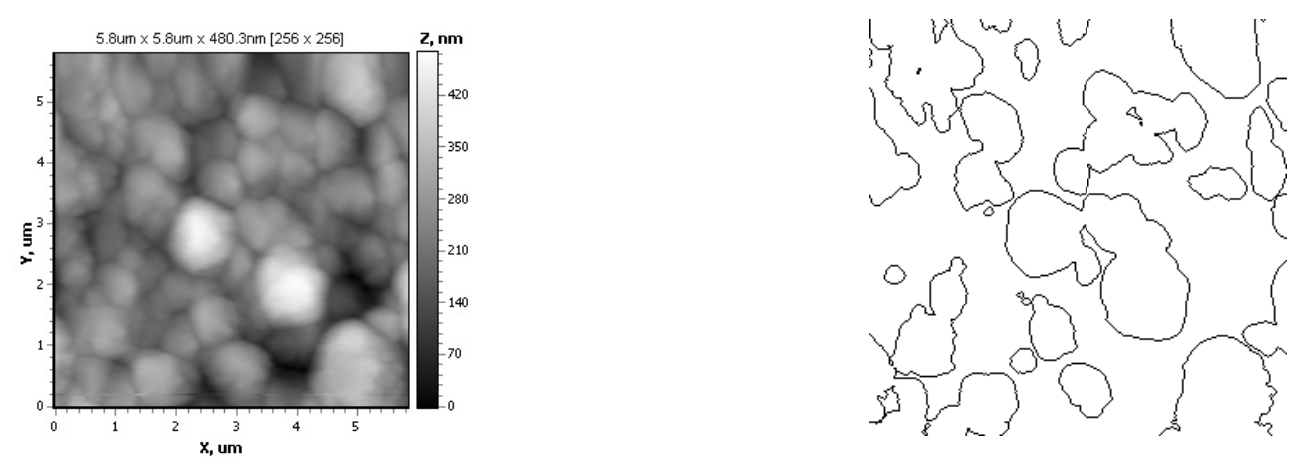

Figure 2. AFM image and the fractal structure of the $\mathrm{Zn}-\mathrm{Al}$ coating $(\mathrm{D}=1.81)$ 
For pure metals, equation (26) is converted to:

$$
f_{G}=\frac{A_{r}}{\mu} \cdot N,
$$

where $\mu$ is the chemical potential of the metal.

For pure metals, the chemical potential coincides with the Fermi energy. In Table 2 these values are given for some metals [39].

Table 2

Fermi energy of some metals [39]

\begin{tabular}{|c|c|c|c|}
\hline Metal & Fermi energy, eV & Metal & Fermi energy, eV \\
\hline $\mathrm{Cu}$ & 7,00 & $\mathrm{Zn}$ & 9,39 \\
\hline $\mathrm{Ag}$ & 5,48 & $\mathrm{Al}$ & 11,63 \\
\hline $\mathrm{Au}$ & 5,51 & $\mathrm{~Pb}$ & 9,37 \\
\hline $\mathrm{Mg}$ & 7,13 & $\mathrm{Sn}$ & 10,03 \\
\hline $\mathrm{Sr}$ & 3.95 & $\mathrm{Ca}$ & 4,68 \\
\hline
\end{tabular}

From equation (35) it follows that the coefficient of dry friction is the smaller, the greater the chemical potential (Fermi energy). Table 3 shows the dry friction coefficients for pairs of the most common materials [40]. In general, the correlation between the Table 2 and 3 is observed.

Table 3

\section{Dry friction coefficients for homogeneous pairs of the most common materials [40]}

\begin{tabular}{|c|c|c|}
\hline \multicolumn{2}{|c|}{ Material combinations } & $\begin{array}{c}\text { Coefficient } \\
\text { dry friction }\end{array}$ \\
\hline $\mathrm{Al}$ & $\mathrm{Al}$ & $1.05-1.35$ \\
\hline $\mathrm{Cu}$ & $\mathrm{Cu}$ & 1.0 \\
\hline $\mathrm{Steel}$ & $\mathrm{Steel}$ & 0.8 \\
\hline $\mathrm{Fe}$ & $\mathrm{Fe}$ & 1.0 \\
\hline $\mathrm{Cd}$ & $\mathrm{Cd}$ & 0.5 \\
\hline $\mathrm{Cr}$ & $\mathrm{Cr}$ & 0.41 \\
\hline $\mathrm{Graphite}$ & $\mathrm{Graphite}$ & $0.5-0.8$ \\
\hline $\mathrm{Mg}$ & $\mathrm{Mg}$ & 0.6 \\
\hline $\mathrm{Ni}$ & $\mathrm{Ni}$ & $0.7-1.1$ \\
\hline $\mathrm{Pt}$ & $\mathrm{Pt}$ & 1.2 \\
\hline $\mathrm{Ag}$ & $\mathrm{Ag}$ & 1.4 \\
\hline $\mathrm{Zn}$ & $\mathrm{Zn}$ & 0.6 \\
\hline
\end{tabular}

If now we bring two dissimilar metals into contact, a contact potential difference $V_{K}=\mu$ will arise. Table 4 shows the values of dry friction coefficients for dissimilar pairs of the most common materials [41].

Table 4

The work function of electrons from some metals [41]

\begin{tabular}{|c|c|}
\hline Metal & $W, \mathrm{eV}$ \\
\hline $\mathrm{Al}$ & 4,25 \\
\hline $\mathrm{W}$ & 4,54 \\
\hline $\mathrm{Fe}$ & 4,31 \\
\hline $\mathrm{Cu}$ & 4,4 \\
\hline $\mathrm{Ni}$ & 4,5 \\
\hline $\mathrm{Sn}$ & 4,39 \\
\hline $\mathrm{Pt}$ & 5,32 \\
\hline $\mathrm{Ag}$ & 4,25 \\
\hline $\mathrm{Zn}$ & 4,54 \\
\hline
\end{tabular}


Table 5 shows the values of dry friction coefficients for dissimilar pairs of the most common materials [42]. Comparison of Tables 4 and 5 shows a significant decrease in the coefficient of dry friction in the case of dissimilar metals in friction pairs.

Dry friction coefficients for dissimilar pairs of the most common materials [42]

\begin{tabular}{|c|c|c|}
\hline \multicolumn{2}{|c|}{ Material combinations } & $\begin{array}{c}\text { Coefficient } \\
\text { dry friction }\end{array}$ \\
\hline $\mathrm{Al}$ & Low carbon steel & 0.61 \\
\hline $\mathrm{Brass}$ & $\mathrm{Steel}$ & 0.35 \\
\hline $\mathrm{Cd}$ & $\mathrm{Cr}$ & 0.41 \\
\hline $\mathrm{Cu}$ & Low carbon steel & 0.53 \\
\hline $\mathrm{Ni}$ & Low carbon steel & 0.64 \\
\hline Wolfram carbide & $\mathrm{Cu}$ & 0.35 \\
\hline
\end{tabular}

The practical use of knowledge about the fractal structure of a solid surface has not yet been studied in detail and it is not yet known in what phenomena it will be decisive (Fig. 2).

Let us consider the well-known phenomenon of cold emission of electrons from a metal under the action of an external electric field, mainly due to the quantum tunneling effect. As is known, the current of cold emission is described by the expression:

$$
j=j_{0} \exp \left(E_{0} / E\right)
$$

where $E$ is the external field strength, $E_{0}$ is the electric field of the metal surface:

$$
E_{0}=\frac{4 \sqrt{2 m}}{3 e \hbar}\left(A-T_{e}\right)^{3 / 2}
$$

$A$ is the electron work function, $T_{e}$ is its kinetic energy.

Above, for the dependence of the electrical conductivity of the film on its thickness $h$, we obtained the following expression:

$$
\sigma=\sigma_{0}\left(1-\frac{d}{h}\right)
$$

where $d$ is some critical size of the film, starting from which the bulk properties «disappear». After the transformations, we get:

$$
\begin{gathered}
j=\sigma E, j_{0}=\sigma_{0} E_{0}, \\
\sigma E=\sigma_{0} E_{0} \exp \left(E / E_{0}\right), \\
\sigma_{0}\left(1-\frac{d}{h}\right) E=\sigma_{0} E_{0} \exp \left(E_{0} / E\right), \\
E=E_{0} \exp \left(E_{0} / E\right)\left(1-\frac{d}{h}\right) \approx E_{0}\left(1-\frac{E_{0}}{E}\right)\left(1-\frac{d}{h}\right) .
\end{gathered}
$$

Denoting $E_{0} / E=z, 1-d / h=k$, where $z$ are complex numbers, and $k$ is real, we get the famous iterative Mandelbrot equation:

$$
z=z^{2}+k
$$

The solution algorithm is quite simple. Iterations are performed for each starting point from a rectangular or square area - a subset of the complex plane. The iteration process continues until $z$ goes beyond the circumference of radius 2 whose center lies at $(0,0)$ (this means that the attractor of the dynamical system is infinite) or after a sufficiently large number of iterations (for example, 200-500) $z$ converge to some point of the circle. Depending on the number of iterations during which $z$ remained inside the circle, you can set the color of point $\mathrm{C}$ (if $z$ remains inside the circle for a sufficiently large number of iterations, the iteration process stops and this raster point turns black).

The following is important for us: the given example shows the fractal structure of the metal surface. Similar patterns are manifested in thermal emission, exoemission of electrons from metals and semiconductors. All this indicates that the fractal structure of the surface of many solids is a characteristic property of them. 


\section{Conclusion}

Summarizing the study, we can draw the following main conclusions:

- non-equilibrium processes in the tribosystem can lead to a decrease in the production of entropy and, consequently, the intensity of wear and stably proceed with the formation of dissipative structures during self-organization;

- it is obtained that the first term from (20) can reach fe $=10^{-3}-10^{-4}$ due to the use of $X_{m}, \rho m$ and $W\left(X_{m}\right)$ in the mode of using special lubricants;

- in space, the effect of oil filters is absent. It uses solid lubricants (TSP) which include substances applied to the surface of parts in the form of films, having a shear strength much lower than that of the part material;

- an expression for the friction coefficient is obtained, taking into account the surface geometry and its physical properties;

- it was concluded that homogeneous vapors of metals should not be used in friction antifriction pairs;

- it is shown that a decrease in the dry friction coefficient is possible due to a decrease in surface energy. In this case, friction pairs are used, in which the electron work function differs significantly. This leads to a difference in the contact potential difference and, accordingly, to a decrease in the surface energy;

- it is shown that the friction coefficient depends on the fractal structure of the surface of many solids and this is their characteristic property.

The work was performed under the program of the MES RK. Grants № $0118 P K 000063$ and № Ф.0780.

\section{References}

1 Крагельский И.В. Развитие науки о трении. Сухое трение / И.В. Крагельский, В.С. Щедров - М.: Изд. АН СССР, 1956. - $235 \mathrm{c}$.

2 Современная трибология: Итоги и перспективы / под. ред. В.К. Фролова. - М.: Изд-во ЛКИ, 2008. - 480 с.

3 Bhushan B. Introduction to Tribology / B. Bhushan. - John Wiley \& Sons. Ltd., 2013. — 711 p.

4 Stachowiak G. Engineering Tribology / G. Stachowiak, A. Batchelor. — Butterworth-Heinemann, 2014. — 884 p.

5 Маленков М.И. Конструкционные и смазочные материалы космических механизмов / М.И. Маленков, С.И. Каратушин, В.М. Тарасов. - СПб.: Балт. гос. техн. ун-т, 2007. -54 с.

6 Мусалимов В.М. Основы трибоники / В.М. Мусалимов, А.А. Сизова, Е.К. Иванов, Н.А. Крылов, А.Л. Ткачёв. СПб.: СПбГУ ИТМО, 2009. - 77 с.

7 Одейчук Н.П. Методика трибологических испытаний углеродных материалов под воздействием ионизирующего излучения и окислительной среды / Н.П. Одейчук, В.К. Яковлев, А.И. Комир, А.Н. Одейчук. — Харьков: НТУ «ХПІ», 2018. № 9(1285). - С. 62-69.

8 Овчаренко В.Е. Трибологические свойства наноструктурированой поверхности металлокерамического сплава на основе карбида титана / В.Е. Овчаренко, Ю.Ф. Иванов // Изв. Томск. политехн. ун-та. — 2008. — Т. 313, № 2. — С. $114-118$.

9 Бакларь В.Ю. Трибологические свойства наноуглерода, полученного электроразрядным методом / В.Ю. Бакларь, Н.И. Кускова, В.В. Тихонович, А.Н. Грипачевский // Электронная обработка материалов. - 2009. - № 4. - С. 30-37.

10 Седалищев В.Н. Обзор существующих методов неразрушающего контроля качества поверхностей с наноструктурированными покрытиями / В.Н. Седалищев, С.П. Пронин, Е.М. Крючков, А.В. Новичихин, М.Ю. Ларионов // Ползуновский альманах. - 2012. - № 2. - С. 176-179.

11 Ермакова С.Ф. Трибология жидкокристаллических наноматериалов и систем / С.Ф. Ермакова // Белорусская наука. - 2014. - $381 \mathrm{c}$.

12 Гаркунов Д.Н. Триботехника (износ и безызносность) / Д.Н. Гаркунов. - М.: Изд-во МСХА, 2001. — 616 с.

13 Кужаров А.С. Свойства и применение металлоплакирующих смазок / А.С. Кужаров, Н.Ю. Онищук. - М.: Наука, 1985. - $60 \mathrm{c.}$

14 Гаркунов Д.Н. О механизме избирательного переноса при трении меди и медных сплавов в среде глицерина / Д.Н. Гаркунов, А.А. Поляков // Контактное взаимодействие твердых тел и расчет сил трения и износа. — M., 1968. — С. $63-$ 72.

15 Кужаров А.С. Концепция безызносности в современной трибологии / А.С. Кужаров // Изв. вузов. Северо-Кавказский регион. Технические науки. - 2014. - № 2. - С. 23-31.

16 Шелевя В.В. Трибохимия и реология износостойкости / В.В. Шелевя, В.П. Олександренко. - Хмельницкий: ХНУ, 2006. $-278 \mathrm{c}$.

17 Юров В.М. Температурные эффекты в спектрах поглощения и люминесценции экситонов в галогенидах аммония / В.М. Юров, Т.А. Кукетаев // Вестн. Караганд. ун-та. Сер. Физика. — 2004. — № 1(33). — С. 46-51.

18 Юров В.М. Безызлучательные процессы и фазовые переходы в кристаллах галоидов аммония / В.М. Юров // Вестн. науки и образования. — 2008. — № 3. - С. 6-12. 
19 Валиев Р.3. Наноструктурные материалы, полученные интенсивной пластической деформацией / Р.3. Валиев,

И.В. Александров. - М.: Логос, 2000. - 272 с.

20 Бершадский Л.И. Структурная термодинамика трибосистем / Л.И. Бершадский. - Киев: Знание, 1990. - 31 с.

21 Пригожин И. Современная термодинамика / И. Пригожин, Д. Кондипуди. — М.: Мир, 2002. — 461 с.

22 Гершман И.С. Реализация диссипативной самоорганизации поверхностей трения в трибосистемах / И.С. Гершман, Н.А. Буше // Трение и износ. — 1995. — Т. 16, № 1. — С. 61-70.

23 Гершман И.С. Синергетика процессов трения / И.С. Гершман // Трение, износ, смазка. — 2006. — Т. 8, № 4(29). C. $71-80$.

24 Чертовских С.В. Анализ трения и изнашивания ультрамелкозернистых материалов с позиций термодинамики / С.В. Чертовских, Л.Ш. Шустер // Вестник УГАТУ. — 2016. — Т. 20, № 2(72). - С. 55-60.

25 Могилевский В.А. Смазочные материалы и присадки. Способы и системы смазывания / В.А. Могилевский, А.М. Лубягов, Е.С. Окулова, Н.А. Глотова. - Ростов н/Д., 2005. — 24 с.

26 Журков С.Н. К вопросу о физической основе прочности / С.Н. Журков // Физика твердого тела. - 1980. - Т. 22 , Вып. 11. - С. 3344-3349.

27 Регель В.Р. Кинетическая теория прочности твердых тел / В.Р. Регель, А.Б. Слуцкер, В.Д. Томашевский. — М.: Наука, 1974. - $302 \mathrm{c.}$

28 Ковшов А.Г. Расчетно-экспериментальная идентификация активационных параметров модели изнашивания поверхностей трения / А.Г. Ковшов // Изв. Самарск. НЦ РАН. - 2016. — Т. 18, № 4(2). — С. 341-346.

29 Блинова Т.А. Зависимость шероховатости поверхности малых отверстий от типа рабочей среды и режимов электроэрозионной обработки / Т.А. Блинова, А.А. Погонин, А.Ф. Бойко // Изв. Самарск. НЦ РАН. — 2010. — Т. 12, № 1(2). C. $301-303$.

30 Колесников В.И. Взаимодействие контактирующих поверхностей при трении / В.И. Колесников, А.В. Челохьян, П.Г. Иваночкин, Е.А. Луговой, А.А. Порческо. — Ростов н/Д., 2000. — 136 с.

31 Юров В.М. Определение коэффициента трения скольжения / В.М. Юров, С.А. Гученко, Н.Х. Ибраев // Междунар. журн. прикл. и фунд. исследований. — 2010. — № 8. - С. 148-152.

32 Юров В.М. Температурная зависимость коэффициента трения / В.М. Юров // Междунар. журн. прикл. и фунд. исследований. - 2010. — № 8. - С. 151-152.

33 Rittinger P.V. Lenbruch fur Aufbereitungakunde / P.V. Rittinger. - Berlin, 1967. — $234 \mathrm{~s}$.

34 Кирпичёв В.Л. Конспект лекций по прикладной механике / В.Л. Кирпичёв. - СПб.: Политехн. ин-т, 1911. - 160 с.

35 Kick F. Das Geserz der proportionalen wederstande und seine. Anwendung Dinglers / F. Kick. — Berlin, 1885. — 167 p.

36 Ребиндер П.А. Понизители твердости породы при бурении / П.А. Ребиндер, Л.А. Шрейнер, К.Ф. Жигач. — М.: АН CCCP, 1944. - $204 \mathrm{c}$.

37 Бонд Ф.С. Законы дробления / Ф.С. Бонд // Тр. Европейского совещ. по измельчению. - М., 1966. — С. $195-208$.

38 Guchenko S.A. Fractal structure of multi-element coating / S.A. Guchenko, O.N. Zavatskaya, V.M. Yurov, S.S. Kasymov, V.Ch. Laurinas // Eurasian Physical Technical Journal. — 2018. — Vol. 15, No. 1(29). — P. 8-17.

39 Киттель Ч. Введение в физику твердого тела / Ч. Киттель. — М.: Наука, 1978. — 792 с.

40 Крагельский И.В. Трение и износ / И.В. Крагельский. - М.: Машиностроение, 1968. — 480 с.

41 Крагельский И.В. Коэффициенты трения / И.В. Крагельский, И.Э. Виноградова. - М.: Машгиз, 1962. - 220 с. $95 \mathrm{c}$

42 Суриков Вал. И. Основы теории твердого тела / Вал.И. Суриков, Вад. И. Суриков. — Омск: Изд-во ОмГТУ, 2016. -

\title{
В.М. Юров, Е.Н. Еремин, В.Ч. Лауринас, С.С. Қасымов
}

\section{Трибологиядағы диссипативтік үрдістер}

\begin{abstract}
Мақалада диссипативті үрдіс қатты денелердегі сыртқы үйкелістің табиғи негізі ретінде қарастырылды. Трибожүйенің тепе-тең емес үрдістері энтропия өндірісінің төмендеуіне әкеліп соғуы мүмкін, демек, тозу қарқындылығы және өзін-өзі ұйымдастыру кезінде диссипативті құрылымдардың қалыптасуымен тұрақты түрде жүруі мүмкіндігі көрсетілген. Арнайы майлауларды пайдалану режимінде $X_{m}, \rho_{m}$ және $W\left(X_{m}\right)$ арқылы алғашқы мүшесі $f_{e}=10^{-3}-10^{-4}$ жетуі мүмкін екендігі анықталды. Ғарышта май сүзгілерінің әсері жоқ. Мұнда, бөлшек материалдарына қарағанда, ығыспалы беріктілігі анағұрлым төменірек бөлшектердің бетіне қабықша түрінде жағылған заттар түрінде қатты майлау материалдары пайдаланды. Беттің геометриясын және оның физикалық қасиеттерін ескеретін үйкеліс коэффициентіне арналған өрнек алынды. Антифрикционды жұптарда біртекті металл жұптардың үйкелісі қолданылмауы керек деген қорытынды жасалды. Беттік энергияның төмендеуіне байланысты құрғақ үйкеліс коэффициентінің төмендеуі мүмкін екенін көрсетті. Бұл жағдайда электрондардың шығу жұмысы айтарлықтай ерекшеленетін үйкеліс жұбы қолданылды. Бұл контактілік потенциалдар айырымының айырмашылығына және тиісінше беттік энергияның төмендеуіне әкеледі. Үйкеліс коэффициенті қатты заттардың беттік фракталдық құрылымына тәуелді және бұл оларға тән қасиет екенін көрсетті.
\end{abstract}

Кілт сөздер: диссипативті үрдіс, үйкеліс, тозу, бет, энтропия, фрактал. 


\title{
В.М. Юров, Е.Н. Еремин, В.Ч. Лауринас, С.С. Касымов
}

\section{Диссипативные процессы в трибологии}

\begin{abstract}
В статье диссипативный процесс рассмотрен как основа природы внешнего трения в твердых телах. Показано, что неравновесные процессы в трибосистеме могут приводить к снижению производства энтропии и, следовательно, интенсивности изнашивания и устойчиво протекать с образованием диссипативных структур при самоорганизации. Получено, что первый член может достигать $f_{e}=10^{-3}-10^{-4}$ за счет использования $X_{m}, \rho_{m}$ и $W\left(X_{m}\right)$ в режиме использования специальных смазок. В космосе эффект масляных фильтров отсутствует. Здесь используют твердосмазочные материалы, к которым относятся вещества, наносимые на поверхность деталей в виде пленок, имеющие сдвиговую прочность значительно меньшую, чем у материала детали. Получено выражение для коэффициента трения, учитывающее геометрию поверхности и ее физические свойства. Сделан вывод о том, что нельзя использовать в антифрикционных парах трения однородные пары металлов. Показано, что уменьшение коэффициента сухого трения возможно за счет уменьшения поверхностной энергии. При этом используются пары трения, у которых значительно различается работа выхода электронов. Это приводит к различию в контактной разности потенциалов и, соответственно, к уменьшению поверхностной энергии. Показано, что коэффициент трения зависит от фрактальной структуры поверхности многих твердых тел и это является их характерным свойством.
\end{abstract}

Ключевые слова: диссипативный процесс, трение, износ, поверхность, энтропия, фрактал.

\section{References}

1 Kragelskii, I.V., \& Shchedrov, V.S. (1956). Razvitie nauki o trenii. Suhoe trenie [The development of the science of friction. Dry friction]. Moscow: Izd. AN SSSR [in Russian].

2 Frolov, V.K. (Ed.). (2008). Sovremennaia tribolohiia: Itohi i perspektivy [Modern Tribology: results and prospects]. Moscow: Izdatelstvo LKI [in Russian].

3 Bhushan, B. (2013). Introduction to Tribology. John Wiley \& Sons. Ltd.

4 Stachowiak, G., \& Batchelor, A. (2014). Engineering Tribology. Butterworth-Heinemann.

5 Malenkov, M.I., Karatushin, S.I., \& Tarasov, V.M. (2007). Konstruktsionnye i smazochnye materialy kosmicheskikh mekhanizmov [Structural and lubricant space mechanisms]. Saint Petersburg: Baltiiskii hosudarstvennyi tekhnicheskii universitet [in Russian].

6 Musalimov, V.M., Sizova, A.A., Ivanov, E.K., Krylov, N.A., \& Tkachev, A.L. (2009). Osnovy triboniki [Tribonics Basics]. Saint Petersburg: SPbGU ITMO [in Russian].

7 Odeichuk, N.P., Yakovlev, V.K., Komir, A.I., \& Odeichuk, A.N. (2018). Metodika tribolohicheskikh ispytanii uhlerodnykh materialov pod vozdeistviem ioniziruiushcheho izlucheniia i okislitelnoi sredy [Methods of tribological testing of carbon materials under the influence of ionizing radiation and oxidizing environment]. Kharkov: NTU «KhPI», 9(1285), 62-69 [in Russian].

8 Ovcharenko, V.E., \& Ivanov, Yu.F. (2008). Tribolohicheskie svoistva nanostrukturirovannoi poverkhnosti metallokeramicheskoho splava na osnove karbida titana [Tribological properties of nanostructured surface of metal-ceramic alloy based on titanium carbide]. Izvestiia Tomskoho politehnicheskoho universiteta - News of Tomsk Polytechnic University, 313, 2, 114-118 [in Russian].

9 Baklar, V.Iu., Kuskova, N.I., Tikhonovich, V.V., \& Gripachevskii, A.N. (2009). Tribolohicheskie svoistva nanouhleroda, poluchennoho elektrorazriadnym metodom [Tribological properties of nanocarbon produced by the electric discharge method]. Elektronnaia obrabotka materialov - Electronic material processing, 4, 30-37 [in Russian].

10 Sedalishchev, V.N., Pronin, S.P., Kryuchkov, E.M., Novichikhin, A.V., \& Larionov, M.Yu. (2012). Obzor sushchestvuiushchikh metodov nerazrushaiushcheho kontrolia kachestva poverhnostei s nanostrukturirovannymi pokrytiiami [Review of existing methods of non-destructive quality control of surfaces with nanostructured coatings]. Polzunovskii almanakh Polzunov's almanac, 2, 176-179 [in Russian].

11 Ermakova, S.F. (2014). Tribolohiia zhidkokristallicheskikh nanomaterialov i sistem [Tribology liquid crystal nanomaterials and systems]. Belorusskaia nauka - Belarusian science, 381 [in Russian].

12 Garkunov, D.N. (2001). Tribotekhnika (iznos i bezyznosnost) [Tribotech (wear and wearlessness)]. Moscow: Izdatelstvo MSHA [in Russian].

13 Kuzharov, A.S., \& Onishchuk, N.Yu. (1985). Svoistva i primenenie metalloplakiruiushchikh smazok [Properties and application of metal cladding greases]. Moscow: Nauka [in Russian].

14 Garkunov, D.N., \& Poliakov, A.A. (1968). O mekhanizme izbiratelnoho perenosa pri trenii medi i mednykh splavov v srede hlitserina [On the mechanism of selective transfer during friction of copper and copper alloys in glycerol medium]. Kontaktnoe vzaimodeistvie tverdykh tel i raschet sil treniia i iznosa - Contact interaction of solids and calculation of friction and wear forces. Moscow [in Russian].

15 Kuzharov, A.S. (2014). Kontseptsiia bezyznosnosti v sovremennoi tribolohii [The concept of wearlessness in modern tribology]. Izvestiia vuzov. Severo-Kavkazskii rehion. Tekhnicheskie nauki - News of universities. North Caucasus region. Technical science, 2, 23-31 [in Russian].

16 Shelevia, V.V., \& Oleksandrenko, V.P. (2006). Tribokhimiia i reolohiia iznosostoikosti [Tribo chemistry and rheology of wear resistance]. Khmelnitskii: HNU [in Russian]. 
17 Yurov, V.M., \& Kuketaev, T.A. (2004). Temperaturnye effekty v spektrakh pohloshcheniia i liuminestsentsii eksitonov v halohenidakh ammoniia [Temperature effects in the absorption and luminescence spectra of excitons in ammonium halides]. Vestnik Karahandinskoho universiteta. Seriia Fizika - Bulletin of the Karaganda University. Physics series, 1(33), 46-51 [in Russian].

18 Yurov, V.M. (2008). Bezyzluchatelnye protsessy i fazovye perekhody v kristallakh haloidov ammoniia [Nonradiative processes and phase transitions in ammonium halide crystals]. Vestnik nauki i obrazovaniia - Bulletin of science and education, 3, 6-12 [in Russian].

19 Valiev, R.Z., \& Aleksandrov, I.V. (2000). Nanostrukturnye materialy, poluchennye intensivnoi plasticheskoi deformatsiei [Nanostructured materials obtained by severe plastic deformation]. Moscow: Logos [in Russian].

20 Bershadskii, L.I. (1990). Strukturnaia termodinamika tribosistem [Structural thermodynamics of tribosystems]. Kiev: Znanie [in Russian].

21 Prigozhin, I., \& Kondipudi, D. (2002). Sovremennaia termodinamika [Modern thermodynamics]. Moscow: Mir [in Russian].

22 Gershman, I.S., \& Bushe, N.A. (1995). Realizatsiia dissipativnoi samoorhanizatsii poverkhnostei treniia v tribosistemakh [Implementation of dissipative self-organization of friction surfaces in tribosystems]. Trenie $i$ iznos - Friction and wear, 16, 1, 6170 [in Russian].

23 Gershman, I.S. (2006). Sinerhetika protsessov treniia [Synergy of friction processes]. Trenie, iznos, smazka - Friction, wear, lubrication, 8, 4(29), 71-80 [in Russian].

24 Chertovskikh, S.V., \& Shuster, L.Sh. (2016). Analiz treniia i iznashivaniia ultramelkozernistykh materialov s pozitsii termodinamiki [Analysis of rhenium and wear of ultrafine-grained materials from the standpoint of thermodynamics]. Vestnik UGATU - Bulletin of UGATU, 20, 2(72), 55-60 [in Russian].

25 Mogilevskii, V.A., Lubiagov, A.M., Okulova E.S., \& Glotova N.A. (2005). Smazochnye materialy i prisadki. Sposoby $i$ sistemy smazyvaniia [Lubricants and additives. Methods and lubrication systems]. Rostov-on-Don [in Russian].

26 Zhurkov, S.N. (1980). K voprosu o fizicheskoi osnove prochnosti [On the physical basis of strength]. Fizika tverdoho tela Solid state physics, 22, 11, 3344-3349 [in Russian].

27 Regel, V.R., Slutsker, A.B., \& Tomashevskii, V.D. (1974). Kineticheskaia teoriia prochnosti tverdykh tel [Kinetic theory of the strength of solids]. Moscow: Nauka [in Russian].

28 Kovshov, A.G. (2016). Raschetno-eksperimentalnaia identifikatsiia aktivatsionnykh parametrov modeli iznashivaniia poverkhnostei treniia [Calculated and experimental identification of the activation parameters of the friction surface wear model]. Izvestiia Samarskoho nauchnoho tsentra RAN - News of Samara scientific centre of RAS, 18, 4(2), 341-346 [in Russian].

29 Blinova, T.A., Pogonin, A.A., \& Boiko, A.F. (2010). Zavisimost sherohovatosti poverhnosti malykh otverstii of tipa rabochei sredy i rezhimov elektroerozionnoi obrabotki [The dependence of the surface roughness of small holes on the type of working medium and modes of EDM treatment]. Izvestiia Samarskoho nauchnoho tsentra RAN - News of Samara scientific centre of RAS, 12, 1(2), 301-303 [in Russian].

30 Kolesnikov, V.I., Chelohian, A.V., Ivanochkin, P.G., Lugovoi, E.A., \& Porchesko, A.A. (2000). Vzaimodeistvie kontaktiruiushchikh poverkhnostei pri trenii [Interaction of contacting surfaces during friction]. Rostov-on-Don [in Russian].

31 Yurov, V.M., Guchenko, S.A., \& Ibraev, N.H. (2010). Opredelenie koeffitsienta treniia skolzheniia [Determination of the coefficient of sliding friction]. Mezhdunarodnyi zhurnal prikladnykh i fundamentalnykh issledovanii — International Journal of Applied and Basic Research, 8, 148-152 [in Russian].

32 Yurov, V.M. (2010). Temperaturnaia zavisimost koeffitsienta treniia [Temperature dependence of friction coefficient]. Mezhdunarodnyi zhurnal prikladnykh i fundamentalnykh issledovanii - International Journal of Applied and Basic Research, 8 , 151-152 [in Russian].

33 Rittinger, P.V. (1967). Lenbruch fur Aufbereitungakunde. Berlin.

34 Kirpichyov, V.L. (1911). Konspekt lektsii po prikladnoi mekhanike [Lectures on applied mechanics]. Saint Petersburg: Politekhnicheskii institut [in Russian].

35 Kick, F. (1885). Das Geserz der proportionalen wederstande und seine. Anwendung Dinglers. Berlin.

36 Rebinder, P.A., Shreiner, L.A., \& Zhigach, K.F. (1944). Poniziteli tverdosti porody pri burenii [Rock hardness reducers while drilling]. Moscow: AN SSSR [in Russian].

37 Bond, F.S. (1966). Zakony drobleniia [Laws of Crushing]. Trudy Evropeiskoho soveshchaniia po izmelcheniiu - Proceedings of the European Grinding Conference (pp. 195-208). Moscow [in Russian].

38 Guchenko, S.A., Zavatskaya, O.N., Yurov, V.M., Kasymov, S.S., \& Laurinas, V.Ch. (2018). Fractal structure of multielement coating. Eurasian Physical Technical Journal, 15, 1(29), 8-17.

39 Kittel, Ch. (1978). Vvedenie v fiziku tverdoho tela [Introduction to Solid State Physics]. Moscow: Nauka [in Russian].

40 Kragelskii, I.V. (1968). Trenie i iznos [Friction and wear]. Moscow: Mashinostroenie [in Russian].

41 Kragelskii, I.V., \& Vinogradova, I.E. (1962). Koeffitsienty treniia [Friction coefficients]. Moscow: Mashgiz [in Russian].

42 Surikov, Val. I., \& Surikov, Vad. I. (2016). Osnovy teorii tverdoho tela [Fundamentals of the theory of solids]. Omsk: OmGTU Publ. [in Russian]. 